\title{
VENUS AND ADONIS: SHAKESPEARE'S CRITIQUE OF SPENSER
}

\author{
BY ELLEN APRILL HARWOOD
}

Mrs. Harwood is a doctoral candidate in English at UCLA

I

$\mathrm{N}$ writing Venus and Adonis, Shakespeare could not have ignored or been ignorant of The Faerie Queene. When Shakespeare published Venus and Adonis in I 593, The Shepheardes Calender (158I) had long since brought Spenser acclaim and renown; Sir Philip Sidney, for example, had singled it out for praise in The Defense of Poetry. In I 590, the first part of The Faerie Queene appeared and was enthusiastically received. Other writers-Nashe, Harrington, Daniel, Drayton, Lodge- heaped praise upon it: The printer's preface to a volume of Spenser's complaints published in 159 I describes the "favorable passage" The Faerie Queene won from the public."

Recently, Donald Cheney has proposed that Shakespeare viewed "The Faerie Queene as his principal challenge as a poem to emulate and surpass" in Vemus and Adonis. ${ }^{2}$ Because of the prominence of Spenser and his work, a version of the Venus and Adonis story published three years after Part I of the epic would not only admit Spenser's poem as a source, but also stand as a critical evaluation of the Garden of Adonis, the Garden's erotic philosophy, and Spenser's Ovidianism.

\section{I}

In The Faerie Queene Spenser attempts to reconcile Ovid and Virgil by combining an Ovidian metaphysics and aesthetics with a Virgilian ethic and purpose. Spenser inherits his solemnity and national purpose from Virgil; his subject matter-what Graham Hough has characterized as "the mazy diversity of actual moral and erotic experience"3-comes from Ovid.

1 See Robert M. Cummings, Spenser: The Critical Heritage (London: Routledge \& Kegan Paul, 1971), pp. 35-100 and "The Printer to the Gentle Reader," Complaints: Containing Sundrie Small Poems of the World's Vanitie, ed. Ernest de Selincourt (Oxford: Clarendon Press, 1910), p. 125. All quotations of The Faerie Queene will be taken from the Oxford University Press paperback, ed. by J. C. Smith and E. de Selincourt, 1970 .

2 Donald Cheney, "Spenser's Hermaphrodite and the 1590 Faerie Queene," PMLA, 87 ( 1972), I99.

${ }^{3}$ Graham G. Hough, A Preface to the Faerie Queene (London: Gerald Duckworth, I 962 ), p. I 22. 
Although Ovid delighted in rewriting Virgil from his own debunking viewpoint, Spenser writes as if Virgil had revised Ovid. The Metamorphoses, lowering the gods to the mundane world rather than raising man to divine heights, questions the Augustan authority which Virgil's epic had implicitly justified. The Faerie Queene, in contrast, subjects Ovidian situations to Virgilian judgment. For example, the Bower of Bliss, in common with much of Spenser's sensuous world, partakes liberally of Ovid, and like the Metamorphoses itself, with its landscape of woods and streams presented in the most polished and sophisticated of styles, prefers nature burnished to a high finish by art. However, the uncompromising Virgilian ethics of The Faerie Queene requires the Bower's destruction.

Britomart, in contrast, satisfies both Ovidian and Virgilian impulses. Smitten with desire, she struggles with her malady like many an Ovidian heroine, but because her love promotes the national interest and thus meets Virgilian standards, Spenser does not require her to renounce it. Her ability to support both Ovidian and Virgilian claims contributes to, perhaps creates, Britomart's success and appeal as a character. In Spenser, unlike Virgil, Ovid, or Ariosto, the epic note need not disintegrate under erotic pressure.

Although Spenser adopts Ovidian narrative techniques, such as multiple, discontinuous plots, he adopts neither Ovidian pace nor Ovidian voice. He abjures both Ovid's economy of verse and tone of playful cynicism. Seriousness and nostalgia, even melancholy, characterize The Faerie Queene. Although Spenser gives rhetorical surface-i.e., style-as much attention as does Ovid, the English poet develops his style in a direction counter to Ovid's. Spenser repudiates urbanity and consision in favor of intentional anachronism and a leisurely, almost incantatory, line and stanza. The Ovidian and Spenserian surfaces rest on opposite ends of a stylistic continuum. Yet, despite these differences between Spenser and Ovid, two of the most Ovidian sections of The Faerie Queene, the Garden of Adonis and the Mutability Cantos, have frequently impressed Spenser's readers as coming, in the words of one critic, "very near to the centre of his poetic belief." "4

In the Garden of Adonis and the Mutability Cantos, Spenser responds to Pythagoras's declamation in Book XV of the Metamorphoses, a speech to which Ovid devotes almost 500 lines. Ostensibly, Pythagoras condemns meat eating and pleads for vegetarianism.

${ }^{4}$ Hough, p. 214. 
He bases his argument in part on the doctrine of incarnation and moves quickly from that point to a more abstract appraisal of change:

In all the world there is not that that standeth at stay. Things eb and flow, and every shape is made too passe away. The tyme itself continually is fleeting like a brooke. For neyther brooke nor lyghtsomme tyme can tarrye still. But looke As every wave dryves other foorth, and that that commes behynd Both trusteth and is thrust itself: Even so the tymes by kynd Doo fly and follow bothe at once, and evermore renew. ${ }^{5}$

Pythagoras lists some of the innumerable examples of change. Night changes into day; the sun rises and sets; the moon waxes and wanes. The very earth undergoes tremendous changes, from mountain to valley or marsh to desert. Animal species give the most impressive evidence for the universal principle of change. The phoenix can even beget life from death. Cities, too, rise and fall. Troy, Sparta, Mycenae, Thebes-all once flourished and now have fallen. Troy, however, Pythagoras continues, will be renewed through Rome. He concludes his speech with a paean to Roman imperial greatness.

The Garden of Adonis is Spenser's recasting of what the Epistle to Arthur Golding's translation of the Metamorphoses calls Ovid's "dark philosophie of turned shapes." Parallels to Ovid begin early in the canto when we are told that Chrysogonee conceived Amoret and Belphoebe "through influence of th'heauens fruitfull ray" (III.vi. 8). The author assures us that "reason" can account for this miraculous phenomenon:

the fruitfull seades

Of all things living, through impression

Of the sunbeames in moyst complexion

Doe life conceive and quickned are by kynd.

(III.vi.8)

Here and in the lines which follow Spenser echoes the passage in Book I of the Metamorphoses describing life after the flood. Similarly, Spenser's "huge eternall Chaos" (Stanzas 35-38) parallels the Chaos of Golding's Epistle and first book. As a matter of fact, Brents Stirling identifies Golding's translation, especially the epistle, as

${ }^{5}$ Golding's Translation of Book XV, lines $197-203$. 
"the probable immediate inspiration" for Spenser's Garden and lists many verbal parallels as evidence. ${ }^{6}$

In addition to verbal echoes, the thrust of the passage as a whole is Ovidian. Both for the seedling babes and for Adonis himself, metamorphosis is the fundamental principle of the Garden. The babes "like a wheele around they runne from old to new" (III.vi. 33). As for Adonis,

All be he subject to mortalitie,

Yet is eterne in mutabilitie,

And by succession made perpetuall.

(III.vi.47)

If the ontological details of the Garden draw on Neo-platonic and Christian sources, the metaphysical foundation remains Ovidian.

In the Garden of Adonis, Spenser adopts an erotic as well as a philosophical Ovid. Ovid's Pythagoras accords sexual generation no special status, and devotes most of his attention to asexual changeastrological, geographical, chemical. But Spenser's Garden of Adonis is an allegory of generation and climaxes in a celebration of sexuality. The Canto first describes unconscious generation. Chrysogonee conceives and delivers without knowing either pleasure or pain. Next, the seedling babes show vegetative reproduction. Finally, we learn that in the Garden "each paramour his leman knowes" and that "right in the middest of that Paradise" stands a mount of blatant sexual symbolism. There "great Mother Venus" "takes her fill" of Adonis, "Father of all formes." Spenser chooses sexual fulfillment as the appropriate metaphor for the force which supports and replenishes the cosmos. Change in the Spenserian world creates as well as regulates, and Spenser's reading of Ovidian philosophy transforms Ovidian eroticism.

Spenser stresses the Ovidianism of the Garden by making the spot the home of Ovidian characters. In this paradisical place grow "every sort of flowre / To which sweet Poetes verse hath given endlesse date" (III.vi.45). Spenser's description of the mount closely parallels Ovid's description of the retreat where Acteon spies Diana. Yet, in the Garden home of Ovidian myth, Spenser bases his story of Venus and Adonis on a non-Ovidian source. In this alternative version, which Spenser may have found in his favorite mythographer,

\footnotetext{
${ }^{6}$ Brents Stirling discusses the sources of Spenser's Garden of Adonis in PMLA, 69 (1934), $501-38$, and $J E G P, 41$ (1942), 482-86.
} 
Natales Comes, Persephone and Venus solve their dispute over possession of Adonis by having him divide the year between them. While Adonis is staying with Venus in the upper world, a boar kills the youth and condemns him to perpetual residence in the underworld. Spenser reverses the ending of the myth to give Adonis "eternall bliss" and "everlasting joy" with Venus. In the Garden, then, Spenser adopts Ovidian philosophy, but not Ovidian plot.

Spenser's dressing of Ovid in non-Ovidian garb is characteristic of his inability to accept Ovid without reservations. Ovid teaches Spenser to accept sexuality, but Spenser can wholeheartedly endorse only that sexuality which Virgil would also approve. This position leads, for example, to the prominence in the Faerie Queene of the Venus Virago or Venus-Diana figure, a hybrid who appears in the first book of the Aeneid.

In order to subject the erotic Ovid to the philosophical Ovid, Spenser also borrows from Neoplatonism. Neo-platonists distinguished Venus Urania, who symbolized the beauty of the divine mind, from Venus Pandemos, beauty realized in the sublunary world. As Erwin Panofsky explains, "while the celestial Venus is a pure intelligentia, the other Venus is a vis gerandi, which . . . gives life and shape to things in nature and thereby makes the intelligible beauty accessible to our perception and imagination." Spenser fuses these two Venuses into one figure in order to teach, in the words of William Nelson, that "earthly love is a reflection, however pale and distorted, of the generative power of the divine." ${ }^{\text {S }}$ Spenser puts Ovid into the service of Christianity without recourse to the heavy-handed allegories of such works as the Ovide Moralisé.

The Garden of Adonis excludes the third Venus of the Neoplatonists, the bestial Venus identified with lust. Spenser ignores animal vegetation. The Canto moves from the vegetative level directly to the human and mythic. The boar, animal passion, must be imprisoned. Spenser sharply distinguishes love with its permissible passion from lust. The narrator assures "Faire Ladies" who "chaste desires do nourish" that Malecasta "was not to love but lust inclined. / For love does always bring forth bounteaous deed" (III.i. 49). Spenser associates lust with the erotic Ovid, Ovid of the love poetry unassimilated to the philosophy of the Metamorphoses.

\footnotetext{
${ }^{7}$ Erwin Panofsky, Studies in Iconology: Humanistic Themes in the Art of the Renaissance (New York: Oxford Univ. Press, 1939), p. 142.

${ }^{8}$ William Nelson, The Poetry of Edmund Spenser: $A$ Study (New York: Columbia Univ. Press, 1963), p. 222.
} 
Ovid's playful attitude toward philosophy in his love poetry vividly demonstrates his difference from Spenser. Ovid puts philosophy in the service of love, not vice versa. The would-be lover is strongly advised to develop his mind and spirit, but only in order to attract women when he has grown old. Ovid's Apollo explains nosce teipsum, "know thyself," as learning to capitalize on one's strong points as a lover. ${ }^{9}$ Spenser portrays this kind of sexuality, sexuality for its own sake, not subordinated to some higher purpose, in the Bower of Bliss. Verdant caught in Acrasia's arms by Guyon's net recalls Venus and Mars trapped in Vulcan's net. In Ovid's world, the capture provokes divine laughter. For Spenser such a dalliance epitomizes sterile sexuality.

Spenser, unlike earlier allegorizers, acknowledges Ovid's moral neutrality. The English poet recognizes that stories from the Metamorphoses can foster the erotic Ovid as well as the philosophical Ovid he prefers. The tapestries in Malecasta's castle, for example, reproduce the myth of Venus and Adonis as told in the Metamorphoses. Spenser carefully presents the panels as ethically disinterested, but admirable for the artist's skill. Like Ovid's carmen perpetuum, the tapestries are "a wondrous work of rare device." But Malecasta and her sycophants have made them the "image of superfluous riotize" (III.i.33). The tapestries adorn a room furnished entirely with beds where Damzels and Squires "swim deepe in sensual desires" (III.i.89). Ovidian love is a heady and dangerous brew.

As well as insisting that erotic interests be subject to philosophy, Spenser limits his acceptance of the philosophical Ovid. In the Mutabilitie Cantos, Spenser returns to the issues and sources which he treated in the Garden of Adonis and clarifies his commitment to Ovidian mutability. Although the Cantos were published after Venus and Adonis and thus are not a force shaping Shakespeare's poem, they are important for understanding Spenser's Ovidianism.

Ovidian antecedents stand behind most of the episodes in the Mutabilitie Cantos. Mutabilitie's genealogy draws upon Ovid's account of Creation in Book I of the Metamorphoses. Her attack upon the moon has the same disastrous results as Phaeton's ride in the chariot of the sun. The council of the gods where Mutabilitie challenges Jove corresponds to the council of the gods in Book I of the

${ }^{9}$ Ovid, The Art of Love and Other Poems, trans., J.H. Mozbey (London: William Heineman, I947), Loeb Library, II.493-510. 
Metamorphoses. The tale of Faunus clearly parodies Diana and Acteon. Natura herself derives in some measure from Ovid's natura of creation in Book I and Pythagoras's "great renewing Nature" in Book XV. Indeed, William Nelson believes that Spenser would have written Book VII on an Ovidian model, as an imitation of Ovid. ${ }^{10}$ Since the I609 Folio identified Book VII as the Legend of Constancy, it seems that Spenser would have built his legend of constancy on the great master of inconstancy, Ovid. Of course, Spenser frequently inverts his sources; after all, he builds his grand epic on Chaucer's burlesque tale of Sir Thopas. In this case, such an inversion would have enabled Spenser to develop his non-Ovidian Ovidianism, his unique fusion of the erotic and moral Ovids.

Mutability evokes very different emotional responses from Spenser and Ovid. Spenser embodies mutability in the figure of a beautiful Titaness; the concept of change retains the creative potential that characterized it in the Garden of Adonis. Mutability's Pageant of the Months and Seasons displays a rich and varied fecundity. But mutability elicits from Spenser a grief and horror absent from his Ovidian source. Mutability may be the way of the world, but that way is a perversion:

Ne shee the lawes of Nature onely brake,

But eke of Iustice, and of Policie,

And death for life exchanged foolishlie;

Since which, all living wights hauve learn'd to die,

And all this world is woxen daily worse.

O pittious worke of MUTABILITIE!

By which we all are subiect to that curse,

And death instead of life hauve sucked from our Nurse.

(VI.6)

Mutabilitie and the fall of man go hand in hand.

Mutabilitie represents the Ovidian notion of change. She contends that "all that moueth, doth mutation loue" (VII.55), and her arguments reiterate Pythagoras's. But unlike Ovid, Spenser cannot sanction random change. Spenser perceives change as having a purpose, or at least a direction. If change produces decay, it can also result in fulfillment. After listening to Mutabilitie's claims, Natura finds 
that all things stedfastnes doe hate, And changed be. Yet, being rightly wayd, They are not changed from their first estate, But by their change their being doe dilate, And turning to themselues at length againe, Doe worke thir owne perfection so by fate, Then ouver them Change doth not rule and raigne But they raigne over Change, and doe their states maintaine.

As Hough so succinctly explains, "The old pythagorean metapsychosis is transformed by the conviction that the soul is a teleological category, that the cycle of birth and rebirth is the soul's striving to realize its own true nature."11 Nature also reveals that the reign of Mutabilitie will not endure: "Time shall come that all shall change, / And from thenceforth none no more change shall see" (vii.59). In the second stanza of the fragmentary seventh canto, Spenser looks forward to "the Great Sabbaoth hight" (lines 7-8). Spenser subordinates change to eternity; nature makes way for grace, but does not contradict it.

Unlike traditional Ovidian allegorists, Spenser does not distort Ovidian concepts until they conform to Christian tenets. He does not insist that Ovid be reconciled to Christianity. Where Spenser cannot make Ovid subservient to Christian precept, he exploits the differences between them. Spenser achieves a new and sophisticated use of the Ovidian allegorical tradition by joining the erotic to the philosophical instead of the rhetorical Ovid. If Spenser gives only a limited assent to Ovidian eroticism and Ovidian metaphysics and none at all to Ovidian rhetoric, he nonetheless accords Ovid an aesthetic approval. Ovid proposes that history may provide an escape from the round of change and Spenser remains confident that only God can do so, but both agree about the immortality of art.

\section{II}

In one of his few astute literary judgments, Francis Meres wrote that "the sweet, witty soul of Ovid lives in mellifluous and honeytongued Shakespeare."12 Shakespeare absorbed the Ovidian spirit as

11 Hough, p. 222.

12 Francis Meres, Palladis Tamia (1598), pp. 28 Iv-282r. 
Spenser could not. For one thing, no attraction to Virgil dilutes Shakespeare's allegiance to Ovid. R.K. Root's survey of Shakespeare's mythological sources lead him to conclude that "the frequency and variety of Shakespeare's references to Ovid" contrast sharply to "the comparative paucity and narrow scope of his Vergilian allusions." ${ }^{13}$ Shakespeare in Venus and Adonis is closer to the Ovidian spirit than Spenser in The Faerie Queene and weds the erotic Ovid to his rhetorical, not philosophical, alter ego. Venus is Shakespeare's Dame Rhetoric. Her words dominate the poem. She speaks for the generative principle which the moral and philosophical Adonis rejects. In fact, much of Venus and Adonis can be read as a repudiation of the erotic philosophy expounded in Book III of The Faerie Queene.

The reunion of Amoret and Scudamour climaxed Book II and the poem in the first edition of The Faerie Queene, the edition available at the time of Venus and Adonis. In this couple Spenser represents an ideal of an earthly love which partakes of heavenly mystery, an immanent transcendent in whom nature flows into grace. The poet compares their reunion to a favorite Neoplatonic image, the hermaphrodite: "Had ye them seene, yet would hauve surely thought / That they had beene that faire Hermaphrodite, / Which that rich Romane of white marble wrought" (III.xii.46). When the two lovers kiss, "no word they spake, nor earthy thing they felt" (II.xii. 45 ). Scudamour runs to his beloved "like a Beare, that greedily embayes / In the coole soile, after long thirstiness" (III.xii.44.7-8).

Shakespeare's thirsty Venus compares Adonis to a deer:

'Fondling,' she saith, 'since I have hemmed thee here within the circuite of this ivory pale, I'll be a park, and thou shalt be my deer:

Feed where thou wilt, on mountain or in dale;

Graze on my lips; and if those hills be dry,

Stray lower, where pleasant fountains lie. ${ }^{14}$

But the goddess cannot persuade Adonis to drink at the fountain of her deer park. Shakespeare describes the kiss the youth begrudgingly bestows upon the goddess in language similar to Spenser's hermaphroditic union: "Incorporate then they seem; face grows to face" (540). The next stanza continues, "He with her plenty pressed,

${ }^{13}$ R.K. Root, Classical Mythology in Shakespeare (New York: Holt and Co., 1903), p. 4. Compare T.W. Baldwin, William Shakespeare's Small Latine and Less Greeke (Urbana: Univ. of Ill. Press, 1944), II, p. 391.

${ }^{14}$ Venus and Adonis, lines 229-234. I use the Pelican edition edited by Richard Wilbur and Alfred Harbarge (Baltimore: Penguin Books, 1966). 
she faint with dearth" (545). A merging which produces mutual frustration instead of shared satisfaction questions Spenser's ideal.

Shakespeare's poem comments as well upon Spenser's portrayals of the Venus and Adonis myth. Readers of The Faerie Queene as distinguished as C.S. Lewis have sensed perversity in the tapestry that portrays the love goddess ogling a dormant boy. But all the critics have praised the union of Venus and Adonis in the garden as an ideal, the very image of nature; that there the "great mother Venus" "possesseth" and "takes her fill" of a "boy" produces neither the least discomfort nor the smallest giggle.

Shakespeare confronts us with the incongruity. His goddess admits, "The tender spring upon thy tempting lip / shows the unripe: yet mayst thou well be tasted" ( I 27-1 28). Later, Venus assures Adonis, "But, $\mathrm{O}$, what banquet were thou to the taste, / Being nurse and feeder of the other four!" (445-446). If the eagerness of Shakespeare's Venus to taste the unripe Adonis strikes readers as distasteful-and it certainly doesn't appeal to Adonis-we should reconsider the satisfaction Spenser's Adonis tenders Venus.

Both Spenser's Venus and Shakespeare's simultaneously enact the roles of lover and mother. While Shakespeare's Venus insists on her desire for Adonis, maternal metaphors suggest contradictory inclinations. The poem likens Adonis caught in "Venus's amorous toils" to a "froward infant stilled with dangling" (562). Venus may prefer an erotic deer park, but she breaks through entwining branches like " $a$ milch doe whose swelling dugs to ache / Hasting to feed her fawn" (875-876). Death's false dart, she bewails, "cleaves an infant's heart" (942). Shakespeare's Venus describes the flower of Adonis maternally and calls her breast its "cradle." Spenser's Venus also laments "the losse of her deare brood, her deare delight," the "flowring herbes and goodly things" which Time mows down (III.vi).

Spenser's goddess has the consolation that her beloved Adonis has become "Father of all forms." Shakespeare's youth is "father" to only a "poor flower" doomed to wither quickly in Venus's breast. The Venus of Spenser's garden need not mourn her lover's death and loss because she is reunited with him. In the Metamorphoses and on Spenser's tapestries, Venus alleviates her grief by changing the youth into a flower. In Shakespeare's poem Adonis melts away and the flower which Venus picks appears without the goddess's volition or intervention. Shakespeare allots Venus more power to destroy than to create. 
Spenser's Venus secures Adonis forever; Shakespeare's goddess loses him forever. The two poets take the myth of Venus and Adonis, a traditional emblem of fertility, in opposite directions. Spenser expands it until the copulation of the goddess and the youth causes and represents universal generation. Shakespeare denies the myth its traditional significance. His Adonis rejects Venus; without their sexual union, cosmic fertilization does not take place.

By choosing a park instead of a garden for his anatomical allegory, Shakespeare further marks his distance from Spenser's vision of love. A garden orders and controls nature. The Renaissance left its parks, especially its deer parks, wilder. ${ }^{15}$ In such a park, man does not subdue nature, but exposes himself to Nature and accepts a limited untamed space. A deer park, like passion, is a small undomesticated space adjacent to civilization as a source of pleasure.

Spenser's Garden of Adonis had excluded the animal world. In the deer park and throughout Venus and Adonis, Shakespeare rectifies this omission. In Venus and Adonis both human and divine qualities rest on a continuum with animal traits. Metaphors describe Venus as hawk and eagle; she herself admits the similarity of her case and the boar's: "Had I been toothed like him, I must confess, / With kissing him I should have killed him first" (I I i 8-i I I9). The goddess's description of the frightened hare characterizes Adonis's situation, and metaphorical comparison of Adonis to such birds as the divedapper point up the animal aspect he does not acknowledge in himself.

In the episode of the horse and jennet, Shakespeare subjects animal passion to a prolonged scrutiny. The stallion and mare, unlike Venus and Adonis, have their sex roles straight. But the horse was commonly "a Platonic symbol of sensuous passion or libido," and when the poem remarks, "Look, what a horse should have he did not lack, / Save a proud rider on so proud a back" (299-300), the narrator seems to remind us, as Spenser would, that passion requires the control of reason. In his essay on "Venus, Adonis, and the Horses," Robert Miller, noting that this episode is the longest non-Ovidian segment of the poem, argues that it reveals the author's moral attitude and concludes that Adonis displays not priggishness, but

\footnotetext{
${ }^{15}$ See entry on "park" in OED and Lilly C. Stone, English Sports and Recreation (Charlottesville, Univ. of Virginia Press, 1960), Folger Booklets on Tudor and Stuart Civilizations, pp. 20-24.

${ }^{16}$ Edgar Wind, Pagan Mysteries in the Renaissance (London: Faber and Faber, I958), p. 8 I.
} 
Renaissance morality, that "it is clear that what the goddess of love desires is abandonment to the enjoyment of sensual pleasure for its own sake."17 Miller would thus compare, rather than contrast, Spenser and Shakespeare.

This incident, however, stands Spenser's hybrid of Virgil and Ovid on its head. With its source in the Georgics and its high epic style, the section where the stallion woos the jennet is unquestionably the most Virgilian section of the poem. But Shakespeare makes Virgil serve Ovid's purposes: the courser teaches the lesson of love. The most Virgilian part of the poem thus becomes the most Ovidian. It does not borrow from an Ovidian source, but duplicates Ovid's method of parodying Virgilian epic for erotic comedy.

Where Spenser fused erotic and epic strains in the service of seriousness, Shakespeare, like Ovid in the Ars Amatoria and Amores, juxtaposes the two for comic effect. Overcoming Adonis's reluctance looms as an epic challenge to the goddess of love: "Her lips are conquerors, his lips obey" (549). Adonis's failure to love is a defeat of epic proportions. Venus achieves "the very lists of love, / Her champion mounted for the hot encounter," only to discover that Adonis "will not manage her, although he mount her" (595-596, $598)$. The narrator attempts to describe Adonis as an epic hero:

And now Adonis, with a lazy sprite,
And with a heavy, dark, disliking eye,
His low'ring brows o'erwhelming his fair sight,
Like misty vapors when they blot the sky.

(I 8 I-I 84)

But Adonis's fretful refusal of love_- "The sun doth burn my face-I must remove" (186)-punctures the heroic description. Love is warfare and Adonis scorns to do battle. At the same time, Shakespeare's goddess fails as a Venus Virago, the figure Spenser so favored.

Like their treatment of the Venus Virago, Shakespeare's and Spenser's attitudes toward pictorialism contrast sharply. Readers of The Faerie Queene have long and often compared it to painting: Pope's famous old lady called the epic a gallery of pictures, and Leigh Hunt crowned Spenser "the Poet of Painters." ${ }^{\text {"18 }}$ But, as Jean

${ }^{17}$ Robert P. Miller, "Venus, Adonis, and the Horses," ELH, 19 (1952), 262.

18 Joseph Spence, Observations, Anecdotes, and Characters, ed. J.M. Osborne (Oxford, 1960), I, I82, and Leigh Hunt, Imagination and Fancy (London, 1883), p. 95. 
Hagstrum points out in his study of literary pictorialism, Ovid also earned accolades as the most pictorial of poets. Description of art works, such as the Palace of the Sun or pieces of weaving, such as Arachne's tapestry, figure prominently throughout the Metamorphoses. Innumerable Renaissance painters and sculptors found subject matter in its pages. Perhaps more than Horace himself, Ovid inspired and shaped the tradition of ut pictura poesis, a tradition crucial to Renaissance art in general and The Faerie Queene in particular. $^{19}$

That Spenser inherits his literary pictorialism from Ovid helps to explain C.S. Lewis's observation that although "fond of describing pictures or tapestries," Spenser usually "puts them in places which he thinks evil." ${ }^{20}$ These evil places—-the Bower of Bliss, Malecasta's Castle, the House of Busirayne-shelter the Ovidian eroticism which Spenser feared. Spenser, who chose not to adopt the movement of Ovidian rhetoric, instead associates Ovid with such static features as his mythic motifs or picture-making, qualities, which, like other Ovidian traits, the English poet assimilates only with reservations.

Shakespeare, however, burlesques the tradition of elaborate set pieces which had developed from Ovidian descriptions. Readers of Venus and Adonis remember Shakespeare's comic portraits-Venus with Adonis tucked under her arm, Venus sweating beneath the midday sun. Because such pictures stand at odds with characterization or language, they further advance the rhetorical dynamic Shakespeare built into the poem. Venus's actions undercut her words. Grabbing Adonis, for example, inappropriately climaxes a beautiful persuasion to love. As Rabkin notes, "time and again her eloquent arguments end in grotesque and risible detail." ${ }^{21}$ Followers of the classical $u t$ pictura poesis tradition searched for the fit and significant detail, not a comic contrast.

Venus and Adonis further rejects pictorialism by articulating the delusion possible in the visual arts. With a formula recalling the Bower of Bliss, the poem likens the Virgilian stallion to a painter's

${ }^{19}$ Jean H. Hagstrum, The Sister Arts: The Tradition of English Pictorialism and English Poetry from Dryden to Gray (Chicago: Univ. of Chicago Press, 1958), pp. 27 and 40. See also Rosemond Tuve, Elizabethan and Metaphysical Imagery (Chicago: Univ. of Chicago Press, 1947), Chapter Three, " $U t$ Pictura Poesis' and Functional Sensuous Imagery," pp. 50-6o.

${ }^{20}$ C.S. Lewis, Allegory of Love: A Study in Medieval Tradition (New York: Oxford Univ. Press, I958), p. 326.

${ }^{21}$ Norman Rabkin, Shakespeare and the Common Understanding (New York: Free Press, 1967), p. I61. 
"art with nature's workmanship at strife / As if the dead the living should excede" (29I-292). Venus, frustrated because Adonis will not rise to the occasion, is likened to "poor birds, deceived with painted grapes," who "surfeit by the eye and pine the maw" (60I-602). Venus comes to recognize Adonis as a "statue contenting but eye alone" (2 13 ). Adonis belongs to the visual arts; Venus, whose words dominate the poem, to the verbal.

A strangely ambivalent attitude toward sight runs throughout the poem. Neo-platonists put the sense of sight at the top of their sensory hierarchy. Ficino, for example, warns that because

the mind, the sight, and the hearing are the only means by which we are able to enjoy beauty, and since Love is the desire for enjoying beauty, Love is always limited to [the pleasures of] the mind, the eyes, and the ears. . . . Indeed, the lust to touch the body is not a part of love, nor is it the desire of the lover, but a kind of wantonness and derangement of a servile mind. $^{22}$

Venus desires to touch and taste Adonis. She pleads, "Touch but my lips with those fair lips of thine" (I I 5). On the basis of this Neoplatonic scale, many critics have judged her reprehensible. According to Lu Emily Pearson, "Venus is shown as the destructive agent of sensual love; Adonis as reason in love. The one sullies whatever it touches; the other honors and makes it beautiful. The one is false and evil; the other is all truth." ${ }^{23}$ Such critics treat Venus as a figure much like Acrasia and assume that Shakespeare views her as Spenser does the mistress of the Bower. Unlike the critics, the narrator of Shakespeare's poem pities Venus's plight. In fact, his sympathy for her increases as the poem progresses. If he regards her at first as an impertinent aggressor, he soon sees her as Adonis's victim, a "good queen," a "poor queen." Her pleading, he decrees, "hath deserved a higher fee" (609).

However much Neo-platonism may illuminate Spenser, it does not supply the key to Venus and Adonis. In Shakespeare's poem, Adonis may exercise the active vision that Neo-platonists praise, but because Venus can imagine, she practices the figurative vision which

\footnotetext{
22 "Marsilio Ficino's Commentary on Plato's Symposium" with a trans. by Sear Reynolds Jayne, The Univ. of Missouri Studies, XIX (1944), p. I 30.

${ }^{23}$ Lu Emily Pearson, Elizabethan Love Conventions (Berkeley: Univ. of Calif. Press, I933), p. 285 .
} 
these mystics sought. ${ }^{24}$ Moreover, Adonis's visual attacks conjure up Petrarchanism more than Neo-platonism. Adonis's eyes, like the starry orbs of any Petrarchan lady, both attract and assault the lover. Entreating Adonis's pity, Venus cries, "Thine eye darts forth the fire that burneth me" (196). At "his look she flatly falleth down" (463) and she complains that his eyes "have murd'red" her "poor heart" ( 502 ). Shakespeare's pattern of visual imagery belongs with his comic role reversal and not to serious philosophy.

Shakespeare adopts Neo-platonic philosophy, as Ovid would, in order to mock mystery. Like its epigraph, the poem itself hints at mysteries only to deny them. The poem carefully identifies Adonis as Beauty, a designation dear to the heart of any Neo-platonist, but this Beauty fails to recognize Love, chief deity in the Neo-platonic pantheon. According to Plato, "All communication between mortals and gods was established ... through the mediation of love."25 Adonis, however, insists, "I know not love ... nor will not know it, / Unless it be a boar" (409-4IO). Adonis mistakes a traditional emblem of lust for love. When the youth rejects the goddess, Beauty rejects Love and the poem denies the chief Neo-platonic doctrine, the unity of love and beauty. Because beauty is not synonymous with love in the poem, Venus and Adonis shatters the Neo-platonic vision of the one.

Adonis refuses union with the divine and his death parodies such mystical unions. The Neo-platonists expressed the love of a god as a mors osculi, because to be loved by a god was to "die," to partake of eternal bliss through the divine. As death, such ecstasy "is bitter, but being voluntary ... is sweet." ${ }^{26}$ In Shakespeare's poem, the boar, not the goddess, bestows a mors osculi upon Adonis; his death is neither voluntary nor sweet. Critics who identify Venus as vicious lust cannot explain why Adonis dies when he has refused her.

And not even stringent application of Neo-platonic standards measures Venus as Lust. Early in the poem, she does deprecate sight. "Art thou ashamed to kiss," she asks Adonis, "Then wink again, / And I will wink-so shall the day seem night" (I2I-I22). She urges him to "be bold to play" because "our sport is not in sight" (124). She welcomes darkness, where Adonis fears "black-faced

\footnotetext{
${ }^{24}$ Rabkin takes a similar position. He sees the poem as presenting "embodied in two characters as two separate principles, the two aspects of love that the neoplatonic Renaissance delighted in seeing paradoxically fused" (p. 159).

${ }^{25}$ Wind, p. $4 \mathrm{I}$.

${ }^{26}$ Wind, quoting Lorenzo di Medici, pp. 130 and 135.
} 
night; desire's foul nurse" (773). But later in the poem, when Venus pities Adonis instead of entreating his pity, the goddess begins to see more. "Sweet boy," she croons, "this night I'll waste in sorrow / For my sick heart commands mine eyes to watch" (583-584). Adonis "glides . . . in the night from Venus's eye" ( 8 I 6 ) and leaves the goddess in a loathed darkness, darkness she once sought:

So did the merciless and pitchy night

Fold in the object that did feed her sight.

Even so confounded in the dark she lay, Having lost the fair discovery of her way.

$(82 \mathrm{I}-822,827-828)$

Later, she tells Death that Adonis's eyes "taught all other eyes to see" (952). Whether we judge by Neo-platonic scales or by the intensity of her grief, Venus moves from lust toward love. The action of the poem teaches Venus, not Adonis, an art of love. Venus discovers the tragic potential of love. Ironically, she learns from Adonis what she had hoped to teach him. ${ }^{27}$

Where Spenser's Venus unites Venus Pandemos with Venus Urania, Shakespeare creates his goddess of love by uniting Venus Pandemos with the bestial Venus. Spenser's Bower of Bliss would appeal to Shakespeare's Venus in her aspect as lust. Gates enclose the Bower in order "their entered guests to keepe within" as Venus in the deer park hopes to hem Adonis "within the circuit" of her arms. The lay of the rose harmonizes with Venus's own carpe diem refrain, and the Bower's delights of sight, taste, and sound would please the Venus who anatomizes the pleasures Adonis offers to each sense. Acrasia works her will "with words" as Venus tries to do. The willing but passive Verdant, asleep after "long wanton joys," so similar to the Adonis of the tapestry, would satisfy every wish of Shakespeare's Venus. But Shakespeare's Venus is also procreative love and needs Spenser's Garden to fulfill her ideal of divine and mortal continuity with Nature. Shakespeare's Adonis would find himself equally uncomfortable in the Bower of Bliss or in the Garden which bears his name. The Shakespearean Venus would welcome both.

\footnotetext{
${ }^{27}$ Although Heather Aslas ("Venus and Adonis: The Education of a Goddess," SEL $\left.{ }_{13}[1973], 31-51\right)$ recognizes Venus's development, she forces the poem into a Platonic scheme.
} 
In Shakespeare's poem, unlike Spenser's, desire and passion cannot be sorted out into good, fertile life-enhancing sex, such as Spenser portrays in the Garden, and evil, sterile sex such as that of the Bower. Both kinds of sex are integral to Venus, simultaneously life-sustaining mother and lustful destroying pursuer. To reject sex because of its double nature, as Adonis does, is to reject life. 